\title{
Drawings in the Air: Digital Sexual Assault as an Event
}

JETTE KOFOED

\section{INTRODUCTION: SINGULARITY AND EVENT ${ }^{1}$}

In this chapter I examine how the spreading of images becomes an event of digital sexual assault. Such spreading involves user generated content which is circulated online (Jenkins et al. 2013); it implicates nudes, social media, fingers that press the 'share' button, decisions to forward images and much more. Yet what might resemble a 'oneness' transforms into prolonged assault and morphs into an affective event.

Based on Spinoza's definition of affect as a capacity to affect and be affected (Deleuze 2007), I investigate a case of digital sexual assault as a matter of such spreading. Through two different readings of empirical data I engage with questions of interfacially mediated affect as a chaotic event. I argue that digital sexual assault is loaded with affectivity and, at its core, that it holds the power to affect and leave traces well beyond what might look like an uncomplicated occasion.

In this chapter you will encounter, among others, a 14 year old, a lawyer, a diagram of how particular sexual images are spread, educational policies, an online campaign against digital sexual assault, and a group of young girls. These elements are all part of unpacking a specific case of digital sexual assault which originates in Denmark and which implicates more than 5000 spreadings, heavy national media dissemination, lawyers, more than 1000 criminal charges, and intense police investigations. This is not an instance of a physical sexual assault, but a case of how the spreading of sexually explicit images, circulated without consent, makes up a digital sexual assault. The case has been coined 'the Umbrella-case.' 
The term 'umbrella' is chosen for a reason, as will be evident later, but the notion of a 'case' is misleading, since this term suggests a singularity and a delimited scope. Nothing could be more wrong. This case escapes being pinned down. It spills over and spreads further with each mention in the media. In this way, not only does the case spread but the difficulties involved in excavating and disentangling this 'case' analytically are obscured. This chapter is thus, to paraphrase Kathleen Stewart (2007), an attempt to "fashion some form of address that is adequate to their form" (4). Hence, the chapter presents findings that are entangled with methodology and ethics, in and through the many facets of the affective event called 'the Umbrella-case.' The case's multi-faceted nature is unpacked through two sets of data.

The chapter falls into six sections. First, I will briefly introduce the Umbrella-case. Second, I will map the theoretical and methodological landscape of the chapter. Third, I will elaborate on how ethics and matters of care are embedded in this specific study of digital sexual assault. In section four and five, the singurality as well as the scatteredness of the case will be unpacked by way of two entangled analyses. The composition of these readings is made up partly of a diagrammatic reading and partly of what I, inspired by Deleuze and Guattari, will call six n-1 dimensions. The diagrammatic reading will present an overview and a timeline of the spreadings of the recorded material, whereas the n-1 dimensions will dwell on minor aspects of what the spreadings also entail. The sixth and final section will show how the phenomenon of unconsented digital spreading of sexualized images is an event that exceeds what might at first resemble a demarcated 'case.'

\section{THE UMBRELLA-CASE: WHOSE CASE?}

The National Center for Missing \& Exploited Children (NCMEC) is an American non-profit, reporting center for the prevention and recovery from child victimization. ${ }^{2}$ In 2015, NCMEC received a report from Facebook revealing numerous requests, correspondences, and spreadings of a number of videos documenting a particular sexual encounter in Denmark. NCMEC subsequently collected correspondence related to the actual spreading of the video and forwarded the reports with IP-addresses to the Danish National Cyber Crime Center (NC3). Subsequently, the $\mathrm{NC} 3$ was responsible for investigations of non-consensual spreading 
and in January 2018 decided to press criminal charges against more than 1000 young people. The indictment charged them with distributing child pornography, as the individuals depicted in the videos were below the age of 18 . Since then, fines and suspended sentences have been passed and, at the time of writing, the Danish Supreme Court has upheld the outcome of trial. When the more than 1000 young people were initially charged in January 2018, the case was coined the 'Umbrella-case' due to a pattern that emerged in visual illustrations of the spreading (see Diagrams 1-6). In the spring of 2018, the case took center stage in Danish media.

A year after the criminal charges were initiated, I met with the lawyer who represented the girl who was digitally assaulted. We met upon my request as I had sought her help to disentangle the case beyond what was possible based on public media accounts. From the outset, we struggled with the ethics of our encounter: Can we talk about this? How can we talk about this without causing further injury to those involved? Is it better left unscrutinized? Does the mere act of writing about this case resemble the spreading itself? We were looking to move in ways which I later realized might be "walking as controlled falling" to use Brian Massumi's term: which describes how to move and move forward with/in constraints rather than attempting to avoid constraints all together $(2015,12)$. But back then, the lawyer summed up our concerns in one sentence: "Her story is not ours to tell."

Throughout this chapter, where needed, I refer to the victim of the digital assault as 'the girl.' This rather mundane way of referring to one of the victims is chosen to not draw attention to the girl. Scrutinizing the empirical data that I collected for this chapter allowed me to focus on the pattern of spreading and the interfacially afforded manifoldness of the event rather than the victims of the assault. This choice places 'the girl' next to the analysis in a position beyond access or knowledge. The reader must therefore tolerate spreading as the focus of analysis. This determined focus on the spreading of videos leaves 'the girl' absently present throughout the analysis. I do not speak of 'the girl,' but remind the reader that the victim/s are at the core of the case, yet analytically set them aside as the core of analysis. ${ }^{3}$ 


\section{DRAWINGS IN THE AIR}

In attempting to convey to the reader how the Umbrella-case is dispersed and yet forms a composite whole, I borrow a term from the Berlin-based Japanese artist Chiharu Shiota. Shiota talks of "drawings in the air" as a manner of describing her artwork "Me, Somewhere Else" (2018). ${ }^{4}$ This artwork includes kilometers of red yarn woven into a vast net hanging from the ceiling, connected to a pair of (fragile plaster cast) feet on the floor. For the purpose of this chapter, the wording of 'drawings in the air' serves as a metaphor for how the spread of the videos is tangible, ubiquitous, yet barely visible and vast. The expression serves as an incitement for connections and as a manner of finding words for how a video produced without consent can be unconsensually shared, and, in spreading, compose such drawings in the air. This metaphor does not privilege the perspective of a particular subject, rather, it offers the sensation of the strings, connected, dispersed, impinged, finding a shape-and yet dissolving in the air as a manner of addressing the ineffable, yet composed matter of the case.

\section{SPREADABILITY}

There is something particular to the phenomenon of user-generated spreading of media content. Images, memes, tweets, cute babies, political debates, and other media content are put in motion in a manner different from broadcasting or publisher initiated distribution. In order to explore the particularity of how the videos of a sexual encounter spread, I follow Jenkins, Ford \& Green's (2013) terminology of 'spreading.' Here the participatory aspect of spreading is stressed in reference to how user generated content is circulated online. Networked communities, they argue, play a key role in how media are spread. Spreadability thus "refers to the potential-both technical and cultural—for audiences to share content for their own purposes, sometimes with the permission of rights holders, sometimes against their wishes" (Jenkins et al. 2013, 3). Jenkins et al.'s concept of spreading stresses the 'doing' of a networked community, yet acknowledges how spreadability also refers to:

the technical resources that make it easier to circulate some kinds of content than others, the economic structures that support or restrict circulation, the 
attributes of a media text that might appeal to a community's motivation for sharing material, and the social networks that link people through the exchange of meaningful bytes (Jenkins et al. 2013, 4).

Accordingly, the concept of spreadability declines to treat the subject, the networked community, the wider political interests, technological affordances, and economics interests separately. For the purpose of this chapter, I follow this line of thinking to explore the core act of 'sharing' as a matter of spreading.

\section{THE THEORETICAL AND METHODOLOGICAL LANDSCAPE}

My effort here contributes to a substantial body of research within cyberbullying and digital sexual assault scholarship (Johansen et al. 2018; DeKeseredy \& Schwartz 2016; McGlynn \& Rackley 2017; Ringrose et al. 2013; Ringrose \& Harvey 2015; Handyside \& Ringrose 2017; Kofoed \& Larsen 2016; Rasmussen \& Søndergaard 2020; Maddocks 2018; Kofoed \& Ringrose 2012; Kofoed \& Stenner 2017; R. Sylwander \& Gottzén 2020; Sylwander 2019; Mortensen 2020; Bjørnholt 2020; Kofoed \& Staksrud 2019). From this vast body of literature, I especially draw on Mortensen's definition of digital sexual assault:

\footnotetext{
Digital sharing of sexually explicit or sexualised images when the person in the image(s) is identifiable (potentially through added data) and has not consented to the distribution; and/or harassment, stalking, shaming and bullying of the victims (Mortensen, 2020).
}

Mortensen specifies how this definition does not include all cases of digital sexual assault and differs from broader definitions of imagebased sexual abuse (McGlynn \& Rackley 2017; Maddocks 2018) by including identifiability and harassment. Mortensen's definition is based on distinguishing between consent at the level of distribution, production, and sexualization which allows her to identify four categories of digital sexual assault. The Umbrella-case is an instance of what Mortensen refers to as "coerced images" (Mortensen 2020, 101). Starting from this definition of digital sexual assault combined with Jenkins et al.'s (2013) terminology of spreading allows me to highlight how this case involves non-consensual sexualization of a body in non-consensually produced 
images that are also spread non-consensually. This is undertaken by a networked community within and through which the spreading moves beyond friendship-based networks.

While the non-consensual spreading of such non-consensual images is at the core of this digital assault, the very act of spreading images is also a mundane everyday media practice that is not always assaultive. I, and others, have argued elsewhere that spreading, tagging, sexting and image based communication are also wanted, desired practices in social media life and that they are important practices for gluing social relations together (Handyside \& Ringrose 2017; Kofoed \& Larsen 2016; Kofoed 2018; Rasmussen \& Søndergaard 2020).

This chapter thus addresses a particular aspect of these practices, an interfacial event which can best be described as highly affective and which entangles cybercrime charges, legislative aspects, national and local media coverage, social media panic, and debates about the responsibilities of tech giants and education, all as a matter of digital sexual assault. Furthermore this chapter situates itself within post-qualitative methodologies, non-representational methodologies, and a feminist practice of care (St. Pierre \& Jackson 2014; Haraway 2016; Puig de la Bellacasa 2017; MacLure 2013; Staunæs \& Kofoed 2015; Lather 2007; Springgay \& Truman 2018; Lather \& St. Pierre 2013; St. Pierre 2017; Hollway 2006; MacLure 2020). St. Pierre argues for a post-qualitative inquiry that cannot be taught or learned since it "comes with no methodology at all, no preexisting rules, processes, methods, categories" (St. Pierre 2017, 687). Inquiry, and not methodology, she argues, involves thinking with concepts, not applying them. My effort here is to think with the concepts of event and affect as these are taken up within a Spinozan and Deleuze-Guattarian tradition, in relation to a matter of digital assault. At the same time, as mentioned previously, I shall not disregard methodology altogether but find a methodological language for how to "fashion some form of address that is adequate to [its] form" (Stewart 2007, 4). I take methodology to mean the effort to open the black box of research practices, not in terms of application of concepts, but in terms of how, theoretically informed, we engage in empirical analysis. In this case, in a high intensity zone of assault (Kofoed \& Staunæs 2015). In empirical scrutiny, we need language and concepts to address the how of thinking with concepts. I follow Springgay and Truman 
(2018) who argue "that it is the logic of procedure and extraction that needs undoing," not methods in themselves. Research methods, in their view, become "a practice of being inside a research event" (2).

I decided to define the Umbrella-case as a research event that lasted over the course of 2018-2020 and to move with the case, inspired by Isabelle Stengers' way of challenging some of "the methodological assumptions associated with the humanistic legacy of qualitative research practices" (as Sarah Whatmore succinctly puts it) $(2003,91)$. I studied the case on a number of occasions and through a number of activities: meetings, social and national media, offline seminars with NGOs, research conferences and (sometimes unsuccessful) interviews.

The temporality of this research event was layered and merged into a present, yet it also allowed for continuous rewindings in a way that can best be described as 'thick time' (Kofoed \& Kousholt 2011; Kofoed 2013b; Kentridge 2017; Juelskjær \& Rogowska-Stangret 2017). My approach to this entangled case works with Deleuze's conceptual definition of the event, asking, "What are the conditions that make an event possible?" His answer is: "Events are produced in a chaos, in a chaotic multiplicity, but only under the condition that a sort of screen intervenes" (2006 [1988], 86). The many occasions enfolded in the chaotic Umbrella-case make up the continuous becoming of such an event.

\section{ETHICS}

"Her story is not ours to tell." This timely reminder originates, as mentioned, from the girl's lawyer. The story of suffering a digital sexual assault is indeed the girl's to tell. Just as it is her decision when and how to tell it. Studying violence raises the question of how to explore cases of assault without adding further violence. When the violent act comprises non-consensual spreading of a sexualized video, the mere act of studying the case bears striking similarities to the spreading itself. Hence, this field of study raises fundamental ethico-political question: How to write about digital sexual assault without adding more violence, further spreading, and more grief to the matter?

In walking the tightrope of the restless ethical predicaments described above, a certain hesitancy was needed. In the context of ethics, I understand hesitancy to mean to pause in zones of high intensity in order to 
find possible ways to move (Kofoed \& Staunæs 2015). Hesitancy has been needed throughout the entire research process: how to ask the very first question, how to engage in a walking methodology of the case (Springgay \& Truman 2018), how to consider the ethical implications of a Deleuze-Guattarian 'take' on event, not least in the very last parts of the process when writing up the analysis. Hesitancy was needed not just in fieldwork, but throughout the research process is a manner of finding an ethico-methodological space for examing the manyness of this event. Just as Karen Barad reminds us, in an interview with Juelskjær and Schwennesen: ethics is woven into every aspect of the research process (Juelskjær \& Schwennesen 2012).

In this particular research, matters of ethics have seemed to be restless. In this chapter I study violence by way of an implicit solidarity with the pain suffered, without a presupposed pinning of pain to particular subjects. I seek to avoid scrutinizing positions of the victims as the entry point for the analysis by excavating fields of digital sexual assault through the spreading itself. To stay with the spreading itself is a manner of staying with the trouble (Haraway 2016), and not casting this kind of violence aside as un-researchable. This endeavour works as a doing and what I have come to think of as a situated alertness reliant upon the affordances of this particular event.

\section{PART I: WHAT KIND OF DATA?}

As mentioned above, $\mathrm{NC} 3$ became the core agent in collecting online data based on the NCMEC reports prior to the criminal charges in January 2018. As part of NC3's investigation, a video of the Umbrella-case spreading was composed with a time-line, shaped as a diagrammatic illustration (Thomsen 2018). According to Deleuze and Guattari, a diagram "retains the most deterritorialized content and the most deterritorialized expression, in order to conjugate them" (2002 [1987], 141). Such conjugation of content (in this case, the aggregated data of ip-addresses and spreadings), "does not function to represent, even something real, but rather constructs a real that is yet to come, a new type of reality" (142). This particular diagrammatic illustration was comprised of aggregated information about the number of shares. The material originally contained highly sensitive information such as e-mail addresses, ip-addresses, names, and inquiries of how to access more videos. These sensitive data-elements were 
removed by $\mathrm{NC} 3$ and are thus inaccessible in this piece of data, instead another, hitherto invisible, "new type of reality" (142) becomes accessible through the diagram as MacLure also argues (MacLure 2020). As underlined by the $\mathrm{NC} 3$, the diagram emerging from the data was not scientifically based, composed as it was with the sole purpose of giving the police an overview of the spreading of non-consensually produced video material. Diagrams 1-6, below, are screenshots of this video diagram. The continuously moving time-line of the spreading is unfortunately lost when represented as freeze-frames: a stillness sticks to and alters the impression of perceptible transformation depicted in the video.

\section{A DIAGRAM OF THE UMBRELLA-CASE}

The diagram made from the Umbrella-case's data of spreading is made up of a moving graph. It is a system of coordinates which illustrates the development over a course of time, from July 2015 through October 2017. The diagram in total has a duration of 3 minutes and 15 seconds.

Each spreading of a video is marked by a dot. Lines indicate whether the video is forwarded or not. The diagram so to speak 'tunes into' the phenomenon by capturing its temporality, and in this sense this diagrammatization of the case is 'starting in the middle,' which is the well-known working 'take' of Deleuze's (2002 [1987]). The NC3 diagram conjugates the aggregated data while displaying the spreadings as an image of an Umbrella. Hence the NC3 video diagram labels the dispersed matter in the singular as the Umbrella case. Two years of spreadings are displayed into six diagrams below.

The NC3 registration of the spreading was restricted to activities on Messenger. At first the spreadings are scarce, then they quickly grow. The rarity and the kick-off from one initial spreading is depicted in Diagram 1. Each red dot indicates a person who has received the video. Within the next month 37 people have passed on the video, all originating from the first initial spreading. This is visible in Diagram 2 where the spreadings form the shape of an umbrella. By mid-September of 2015 the spreadings speed up and new points of origin occur. This is visible on Diagram 3 where new red dots spark new shapes of umbrellas. In Diagram 3, a red line at the bottom becomes visible indicating ip-addresses that received the assaulting video but refrained from passing it on. Throughout September and into October of 2015 new shapes of umbrellas, i.e. new points of origin, occur. 


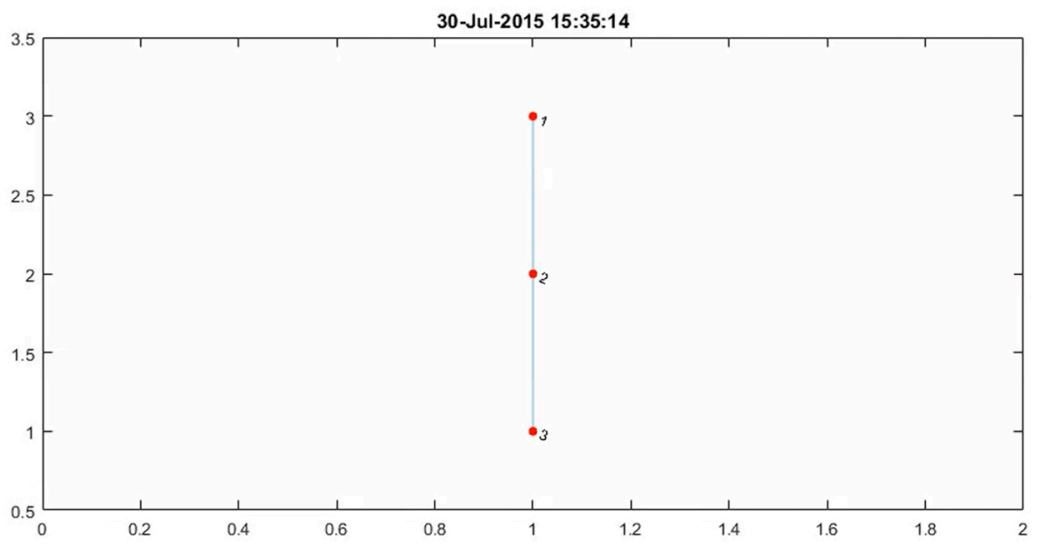

Diagram 1. Spreading, NC3, July 2015.

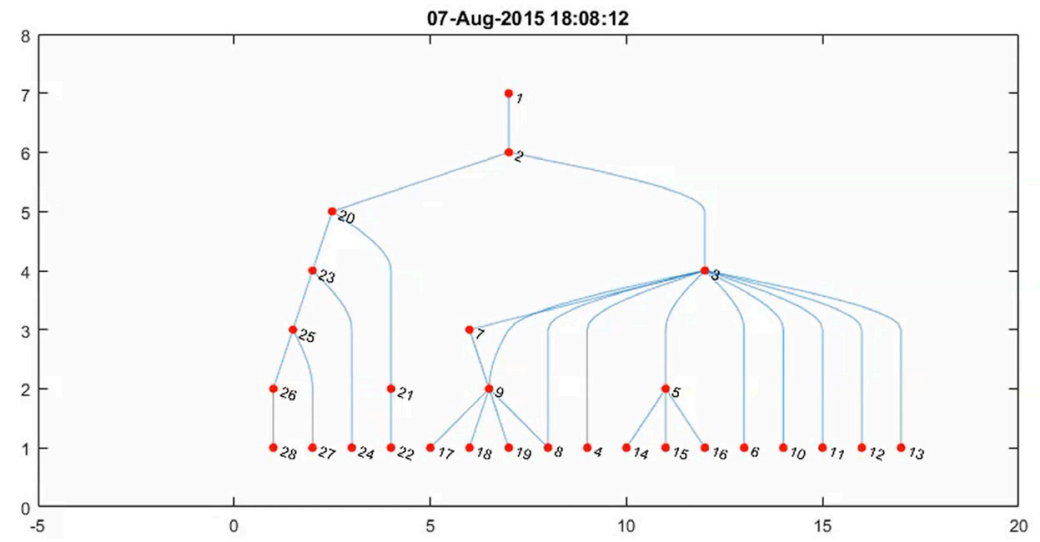

Diagram 2. Spreading, NC3, August 2015.

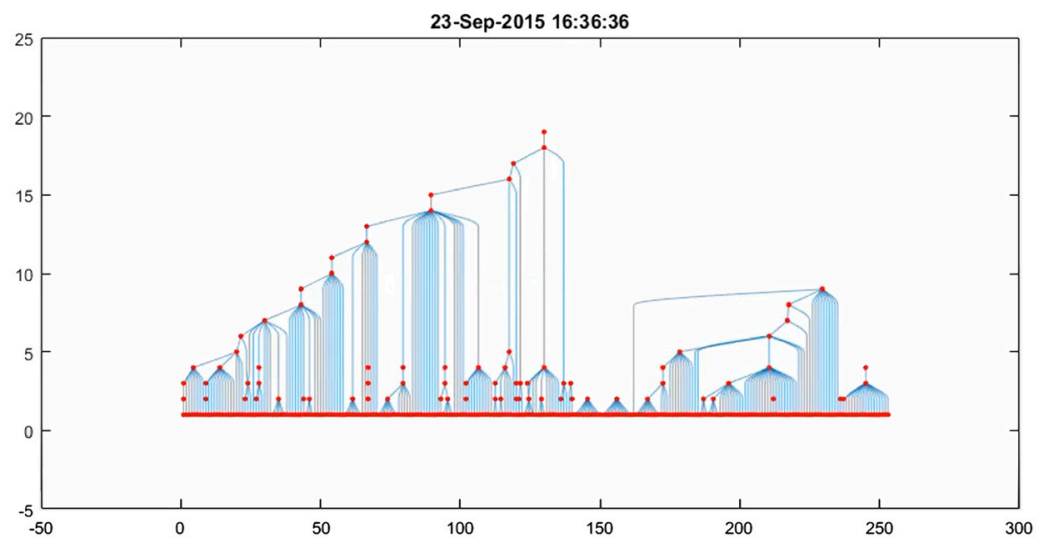

Diagram 3. Spreading, NC3, September 2015. 
By December 2015 more than 2000 spreadings had taken place. This continued exponentially until it reached approximately 4000 spreadings by April 2016. As shown in Diagram 5, by May 2016 the pattern densified. The spreadings then continued at a slower pace until reaching a total of 5000 by August 2017. Another lull occurred around March-July 2017 followed by a new peak in August 2017. This peak could possibly be related to the release of a song composed of cuts from the video. When uploaded on streaming sites, the song spurred new requests for the assaulting video material. The NC3 registration of spreading stops by October 3, 2017.

Diagrams 4-6 show how the identifiable patterns of umbrellas intensify in density. They dissolve into blots and take a form resembling a city skyline in Diagram 5. At the same time red dots form a distinct red line at the bottom. Hence, the diagram shows a thickening line of those that decide to not pass on the video. At the same time the shape of the identifiable umbrellas dissolves into dots and blots at the point where more than 4000 spreadings have been reached.

Greg Seigworth's description of affective encounters as "points of affect" is helpful in thinking about the representation of spreadings as dots:

As a kind of intensity or touch. To touch and/or be touched by something. A point of contact with another thing, another body. An encounter. An impingement. Point as the moment of relation of a body to other bodies, of things to other things (2019b, 1).

In the diagram such points are representing contact between ip-addresses. Seigworth argues that such pointed encounters, "are the kind of events that happen on all kinds of scales" (1). In this case, looking at affect as points directs our attention to the multiplicity and specificity of points indicating that a media exchange has taken place. Conceiving affective encounters as 'touches' and 'impingements' is thus literally depicted in the video's diagrammatisation of the spreadings. By showing the umbrella-like patterns increasing over time as impingement rather than as numbers, readers are allowed a mediated impression of the 'points of touch' by proxy. The registrations of points of spreading make it possible for the viewer to see and feel the assault of the spreading as the unending but apparently harmless 'shareability.' Each point thus marks a kind of negative affective encounter. 


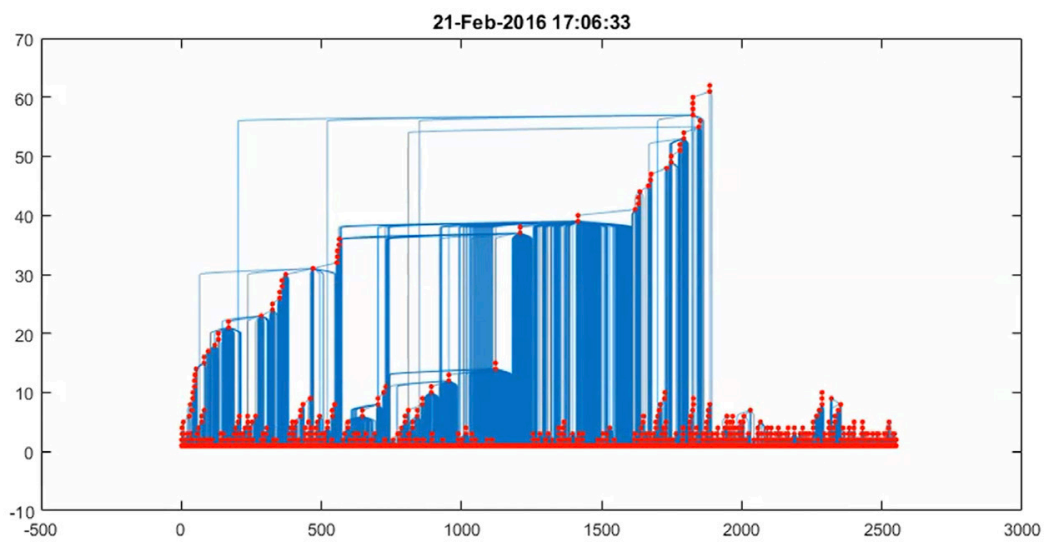

Diagram 4. Spreading, NC3, February 2016.

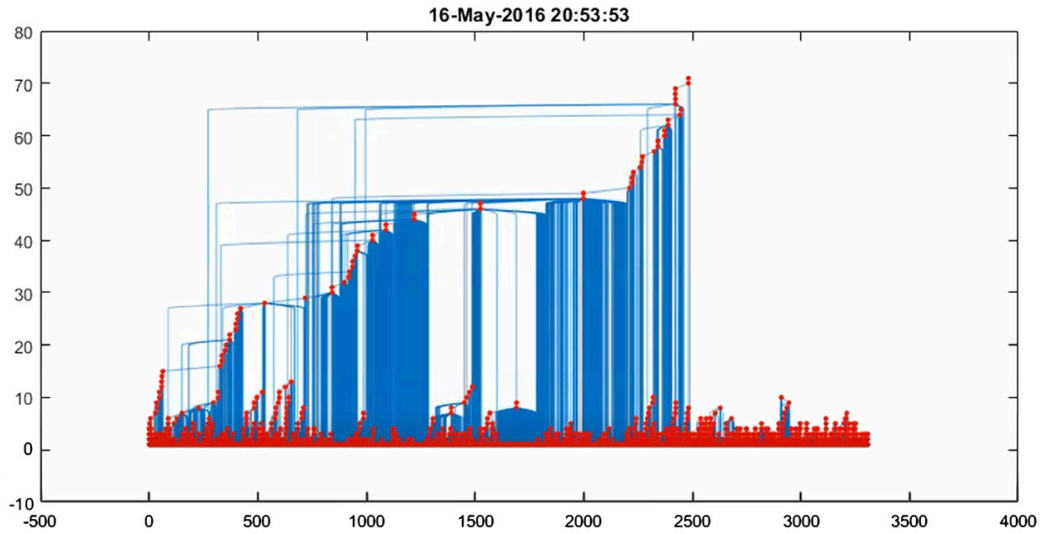

Diagram 5. Spreading, NC3, May 2016.

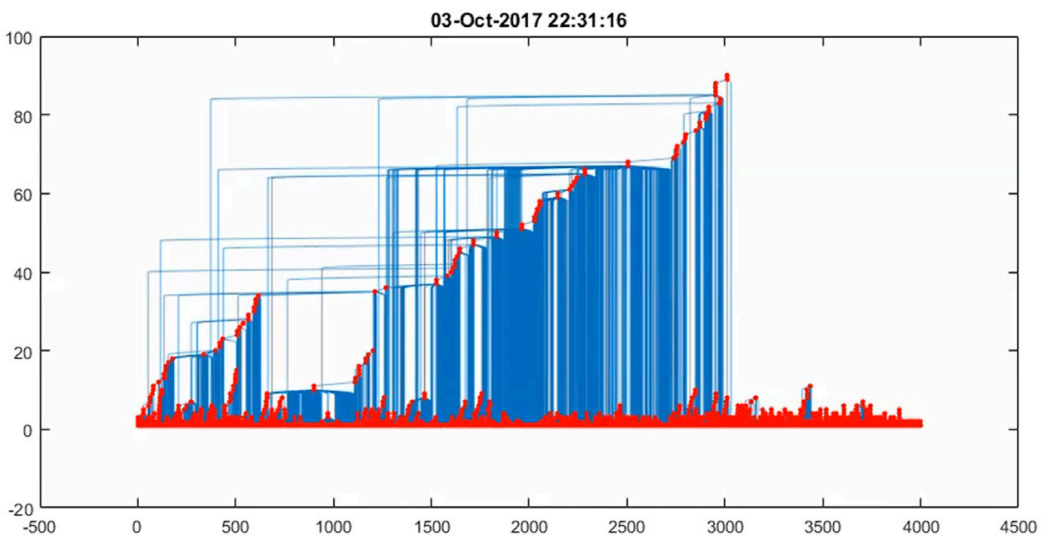

Diagram 6. Spreading, NC3, October 2017. 
In the diagrammatic illustrations the points merge into lines and even into blots, and possibly into more. We might see in this 'more' what Seigworth refers to as a 'plane of immanence,' to help us address what might be at stake:

Affect, in this third mode [immanence], is a measure of co-constitutive open-
ness of bodies \& worlds, to ongoing immersion in a plane of immanence.
Deleuze says this is Spinoza's blessedness of monistic substance as God or
Nature: the infinite connectedness of everything in unmediated relation
[...]The single plane that holds the other two registers in all their multiple
pinprick impingings \& continuous variations, stretched to their widest. But
keep in mind too that this plane has been there all along-in its throwness.
It persists alongside every point, every line. It shifts and waves, circulates and
murmurs as it is reconfigured, redrawn, as it shimmers in the motions and
intensities of bodies that compose it (7).

The affectivity of the unfolding of the event, one could say, is pointed, lined and also possibly lived in what Seigworth addresses as "an ongoing immersion in a plane of immanence," and terms thrownness (6). Such mergings of points into lines, into planes, showcase how the spreadings are not happening in isolation, but the pattern of the spreadings themselves suggests that the points impinge on certain bodies. The merging of the points into blots can suggest that not only distinct individuals at the receiving end are affected by the spreadings, stretched to its widest. The affective event happens in its singurality, as well as in its abundant multiplicity, and in its thrownness.

\section{PART II: A MATTER OF MOVING WITH}

Whereas the diagram depicts the case from a distance, this part of the analysis is embedded in a methodology of the middle and n-1 dimensions (Kofoed, 2013a; Deleuze \& Guattari, 2002 [1987]). Deleuze and Guattari refer to this as "the principal characteristics of a rhizome":

It is not a multiple derived from the One, or to which One is added $(n+1)$. It is composed not of units but of dimensions, or rather directions in motion. It has neither beginning nor end, but always a middle (milieu) from which it grows and which it overspills. It constitutes linear multiplicities with $\mathrm{n}$ dimensions having neither subject nor object, which can be laid out on a plane of consistency, and from which the One is always subtracted (n-1) (2002 [1987], 21). 
The multiple is thus not just a matter of adding, but also of subtracting, Deleuze and Guattari caution. So, in the remaining part of this chapter, I will make an effort to convey to the reader an impression of the excessive event of the Umbrella-case, heeding Deleuze and Guattari's advice:

The multiple must be made, not by always adding a higher dimension, but rather in the simplest of ways, by dint of sobriety, with the number of dimensions one already has available-always $n-1$. [...] subtract the unique from the multiplicity to be constituted; write at n-1 dimensions (6, italics original).

The dimensions are disparate and do not compose a single whole, or deepen into the most important aspects of the case, nor do they work through meaning, but rather in a manner where the interfacial density of the case might play out, just as the diagrammatic reading showcased how points coalesce into blots and suggested how the spreading might (also) be comprehended.

The following $\mathrm{n}-1$ dimensions are written in the present tense. Rather than merely transforming the experiences of fieldwork into texts by making an ethnographic presence explicit (Hastrup 1990; Baarts 2010), writing in the present tense is here a manner of conveying a coalescence of multiple temporalities referring to aion as the infinite time of the event, and chronos as the time-measure (Deleuze \& Guattari 2002 [1987]). The past tense would be in danger of implying a pure, sequential series of incidents following one after the other. Throughout the dimensions, I also make use of the writer's 'I.' The 'I' is present not autoethnographically (Ellis 2003), but simply to remind the reader that these dimensions are far from exhaustive and that they are experienced in and through the researcher with all the coloring of impressions, perceptions, and situatedness this entails.

\section{$\mathrm{N}-1$}

By January 2018, the more than 1000 preliminary criminal charges for spreading child pornography have been pressed and the news is all over the Danish media. I meet with a girl who narrates how she and her friends, a group of six or seven 16-17 year old girls who have met in the local park; some of them know of peers who have been summoned by the police, others fear they will be charged themselves. Some have seen or forwarded the video, others have not. They feel unsafe and upset. They try to map the damage in their close social circles and replay their own social 
media exchanges. Rumors have it that, if you are charged with the offense of spreading child pornography, it will be noted in your criminal record. The criminal charges are an interruptive turmoil which spur the group of girls to debate whether it is fair to have your future work life damaged for passing on a video when you did not know that it was a criminal act. What is a criminal act? Does the video document an assault or consensual sex? Can you tell from the video? It seems that the event happens to these girls instantly. They do not act in unison even though it could be said that they are cued by the same occurrence.

During the very first days of knowing of the criminal charges, these girls are concerned. All there is, is not knowing exactly; they sense the interruption. Their inclination is to worry about individual future lives in a fast forward movement, while also rewinding into their own media practices and what they have shared with each other: Who did what, when? What happens next? Temporality is sped up, begins anew, while concern about who is to blame takes hold. Possible futures and the past seem to be reworked in the affective quality in that present instant of concern.

\section{$\mathrm{N}-2$}

I visit friends for dinner. We find ourselves in a conversation about social media use and the 14-year-old at the table sighs heavily when narrating how they-at school-are told the same lesson over and over again: "Every time the teachers don't know what to do-they invite [a particular Children \& Youth NGO] to teach us how not to share images on the internet. They lecture us how we need to think carefully before sharing images, and how we need to not be part of another Umbrella-case." The 14-year-old's annoyance is felt when he explains how they have had such similar sessions three or four times over the last couple of months: "Every time there is a vacant spot in the schedule, we are told the same lesson: Don't share! They truly believe that they are teaching us about online safety."

By January 2020, some five years after the initial spreading and two years after the first criminal charges, traces of affect-beyond what you might be tempted to isolate as an 'original' case-are affecting bodies of students, education, parents, and dinner conversations. The Umbrella-case has travelled into schools and has paved the way for repetitive 
teachings, presenting itself as a vector in $8^{\text {th }}$ grade teaching by means of affective amplification infused by educational eagerness to ensure lines of demarcation: don't share!

This dinner, this account of feeling that 'they-do-not-understandwhat-youth-life-is-about' is not following from the charges or the spreading itself: it is the event of spreading. Educational worry is at stake in the next dimension as well.

\section{$\mathrm{N}-3$}

A parent to a $6^{\text {th }}$ grader talks about how a particular message is a callout to parents on the school intranet to make sure to prevent their children from seeing harmful videos online. The media-coverage of the Umbrella-case coincides with the online circulation of another video recording, which also took media center stage and relates to spreadability. This other video documents the assassination of two young Scandinavian travellers in Morocco. The call-out from the school principal is a warning to parents to make sure their children do not see any of these videos. The message is an encouragement not to share and distribute further, but also to prevent young people from seeing the footage. Worry, concern and fear of not knowing how to protect children and young people - the Umbrella-case is felt beyond its immediacy of registered spreadings. It constitutes a collective memory and merges with other cases of spreading, leaving traces on school intranets and parents trying to make sense of such warnings.

\section{$\mathrm{N}-4$}

In Febuary 2020, some five years after the initial spreading, the Danish Ministry of Equality, supported by the Ministry of Justice, launches an online campaign entitled "Digital assaults cost." The overall aim is stated as the need to educate young people about which online actions are illegal. The connection to the Umbrella-case is explicit. One of the YouTube videos features a member of a semi-known pop band. He testifies to having shared one of the Umbrella-case video and states:

I received an offensive video on Messenger. I saw it, people were talking about it at the time 'oh, you should have a look!' So I forwarded it to others. We did not think about it at the time. But we should have. By one click you take part in ruining somebody else's life. I later received a letter from the police. I was 
interrogated, I served as a witness and I slowly realized what I had taken part in creating. I was convicted. I feel bad-I am not that kind of person, but I have been part of it. That is the truth... I was part of it [my translation].

I receive the notification of the campaign release in my Facebook feed. The link is shared by a social worker engaged in police-social work with young people in suburban Denmark. The overall message of the YouTube videos of the government initiated youth-to-youth campaign is that non-consensual sharing is harmful, illegal, and has severe consequences for all parties involved. It particularly problematizes victim-blaming and slut-shaming with an overall message of the need for consent and taking responsibility for one's actions as the appropriate way to move forward. The case not only permeates education settings and imaginaries of assassinations, it also leaves traces in ministerial admonitions to youth. This is not surprising, but nonetheless indicative of how the spreadings potentiate beyond the 'case' and how the relational event "takes up the past differently" (Massumi 2015, 50). Some want to teach young people a lesson. For others the campaign brings renewed attention to the Umbrella-case. Scrolling through the comments to the campaign on YouTube I find questions such as: 'where do I find the video?' and 'what did he do?' The act of spreading is hence not limited to the videos being passed on originally; educational attention such as the ministerial campaign and media coverage also bring renewed attention.

\section{$\mathrm{N}-5$}

When I met with the lawyer we agreed on not telling 'her story.' What we did discuss was the lawyer's story. Prior to this case, the lawyer had not been engaged in legal cases of digital assault. By the time of our meeting, she has spearheaded changes in legal practices, initiated modifications in how the police investigate cases of digital assault, lobbied politically and she still (at the time of writing) is a pronounced voice in media debates. She argues for the need to take societal responsibility for changing the phenomenon of digital assault as, in her words, "a Wild West without legislation." Throughout all of this, her own work life has changed profoundly. Having taking on these cases, she thinks of herself as protecting the vulnerabilities of those experiencing digital assaults. Changes have come about. Nonetheless, uncertainties, potential shaming, 
and the urge to spur political and societal changes have spilled beyond the 'case' and into the lawyer's work- and family life. Even the lawyer feels unprotected. She is uncertain when and how the shielding of her clients will be torn away. If a shitstorm hits, will she be able to protect herself, her family and her clients - or not?

The uncertainty of the event is not limited to this case, nor to the criminal proceedings. The case has imprinted itself on the lawyer's life in ways that constitute pointed impingements (Seigworth 2019b) as well as thrownness as murmurs of unspeakable frailty in similar, yet different, microperceptions of how the event persists in relations of affect. The event lives in $6^{\text {th }}$ floor offices as well.

\section{N-6}

As a hotspot for the changes the lawyer wishes to see, she has initiated the organization Digital Responsibility whose purpose is to "prevent and combat digital assault." "We unite in an effort to inform, educate, and activate all who get in touch with digital assaults. We are Digital Responsibility," it says on their website. ${ }^{5}$ The organization works to spot new cases and new digital phenomena, to prevent further spreading and to find ways to prevent digital violence. Digital Responsibility hosts working groups and meetings, and celebrated its third anniversary in January 2020. The celebration was a networking event which consists of invited talks on research, counseling, tech, and legislation. Since its founding, the organization has become a high profile player among children and youth NGO's, researchers and activists in Denmark, sharing the explicit aim to legally recognize digital assault as a severe crime on a par with offline assault, and to combat digital assault. A strong story line of victimhood of digital assault as never-ending and inescapable once it has occurred is by now well-established. ${ }^{6}$ Some three years after the charging of the more than 1000 young people, the Umbrella case is still mentioned as the case that inspired the founding of the organization (hence the coining of the term). It now entangles with other testimonies of digital sexual assaults in an affective charge of care and politicized awareness where snacks, wine, and affective networking is also the event. 


\section{WHAT COULD BE GOING WRONG?}

"What could be going wrong with the treatment of an issue?" Maria Puig de la Bellacasa asks $(2017,47)$. The non-consensual spreading of videos has disrupted lives. This has been the vantage point of this chapter. The assault happened in a manner where interfacial affordances permitted an act of violence to twist and turn into a different, yet entangled, online assault where the act could not be forgotten, deleted or left in a private sphere. The subsequent criminal charges may have added a sense of justice for some while adding violence to others, and sparked potential criminalization of a mundane youth practice for yet others, while potentially also fueling further spreadings.

The lurking issue of 'going wrong' when scrutinizing this particular event centers around care in how to cover an event that is by no means a homogenous whole, and "not merely becom(e) 'spokespersons' of those who don't ask for it" (Puig de la Bellacasa 2017, 47). I have made not speaking for the girl my vantage point. The balancing act here is, as mentioned, a matter of "walking as controlled falling" (Massumi 2015, 12). This means not neglecting a current form of interfacially afforded violence, not pinning violation to certain bodies without their permission, not attuning to those seemingly at the core of the case, which resembles what Staunæs and Raffnsøe (2019) investigate as an ethics of cutting connections. This balancing act also means scrutinizing how spreading unconsented sexualized images becomes an interfacially afforded affective event and acknowledging that spreading and sexting are also mundane, desired, everyday social media practices.

Walking as controlled falling is thus, as Massumi (2015) says, dealing with such constraints of gravity and letting go of the need for equilibrium, in my case here in simultaneously not attuning to and embedding the case in its wider entanglements. Such letting go is most intensely felt in the crafting of the case in and through its eventfulness and how I have been drawn in to it. It can best be described as a restless ethics in the balancing act of attuning and not attuning in an effort to grasp what could be going wrong. 


\section{IN CONCLUSION, ACROSS DIAGRAMS AND DIMENSIONS}

This chapter is therefore based on a walking that has assessed what kind of potential the acts of spreading tap into and how this charges what we might do next. The 'case' makes sense in the singular tense. Such "thisness" (Seigworth 2019a, 1) is sedimented into both the offline occasion that happened, and is sedimented into an online prolonged assault and the "ongoing-ness" (1) of the same.

This is a finding of how digital sexual assault matters, but a finding which is also deeply entangled with matters of ethics and methodology. The above dimensions give texture to what the relational and affective event is also about, and what it will have become. Throughout this chapter I have invited the reader into this affective event via the relative ineffability of how the 'case' is seemingly situated in a kind of such singularity. The sequential or umbrella-like nature of these spreadings is on the one hand quite tidy in its patterns and yet disorderly. It is singular, yet multiple; demarcated, yet morphing and spilling over. I have needed a methodology and ethics that would allow for walking with such morphings and spreadings out into diagrams and further dimensions.

The singularity of the case makes sense, yet transforms from an offline occasion via criminal charges and heavy media coverage into prolonged digital sexual assault and spreadability. Even though the $\mathrm{n}-1$ dimensions may be vague and difficult to pin down, they serve as affective intimations of what an interfacially afforded affective event of digital sexual assault is. We can recognize the continuous ongoing-ness in a sort of rhizomatic relay. In the above dimensions the group of girls, the lawyer, the pop band, the Minister of Equality, the 14-year-old are all affected and respond differently even though they can be perceived as "inhabitants of the same affective environment" (Massumi 2015, 57). An event, says Massumi, "cannot be fully predetermined. It will be as it happens" (12). The disparate spreadings and the dimensions are not only knotted together by interfacial technologies, the interfaces fashion the relationalities within what happens as part of the event. Hence, the ongoing-ness could not have happened without the entanglement of humans, policies, education, and technology. NC3 registrations of the spreadings focused on Messenger. However, many more platforms are involved and allow for more interfacial foldings to occur: The lawyer's efforts seek the removal of images from all social media and online platforms, the Ministry engages on YouTube, the 
girls check their smartphones, the schools warn parents on the intranet. In this chaos some ended up being assaulted by data streams. This event not only happened, it could not have been predetermined.

Keeping in mind the metaphor of 'drawings in the air,' the identification of both the diagram and the less definable fluidity of $n-1$ dimensions might resemble drawings in the air which is a reminder of both the dispersion and the simultaneous composition of events taking place. Throughout this chapter, 'drawings in the air' has served as a reminder of how someone has been violated, although I have not asked for her story. The metaphor also works as a reminder of how the singularity of the case as well as the ambient manyness of the event's form should be embraced in order to encompass this interfacially afforded event, filled with affects beyond its own apparent umbrella-like composition.

\section{NOTES}

1. This chapter has benefitted profoundly from conversations with and readings by Malou Juelskjær, Ida Wentzel Winther, Nina Javette Koefoed, Signe Uldbjerg, Bodil Marie Stavning Thomsen, and Wendy Hollway.

2. National Center for Missing \& Exploited Children (2021). https://www.missingkids. org/HOME [accessed 18 April 2020].

3. The girl has been invited to contribute to this chapter and, for good reasons, chose not to. Her lawyer has approved the chapter.

4. Chiharu Shiota's artwork Me somewhere else (2018). Available at https://www. chiharu-shiota.com/me-somewhere-else [Accessed 16 September 16 2020]; Video to Chiharu Shiota describing her art. Chiharu, S. (2018) Beyond Time. Available at: https://www.youtube.com/watch?v=L51F-TLl_Tk, [Accessed 26 May 2020].

5. Available at: https://digitaltansvar.dk/ [Accessed 18 March 2020.

6. For a problematization of this storyline, see ULDBJERG, S. 2020. Writing Victimhood: A methodological manifesto for researching digital sexual assault Kvinder, Køn \& Forskning, 2. 


\section{REFERENCES}

Bjørnholt, M. (2020). Theorising Sexual Violence in Intimate Relations in Scandinavia. In: M. B. Heinskou, M.-L. Skilbrei \& K. Stefansen, eds., A Nordic Research Agenda on Rape and Sexual Violence, 1, Oxfordshire: Routledge.

Baarts, C. (2010). Håndværket. Opbygning af viden. In: K. Hastrup, eds., Ind i verden. En Grundbog I Antropologisk Metode. København: Hans Reitzels Forlag.

Dekeseredy, W. S. \& Schwartz, M. D. (2016). Thinking Sociologically About Image-Based Sexual Abuse: The Contribution of Male Peer Support Theory. Sexualization, Media, \& Society 2 (4), pp.1-8.

Deleuze, G. (1988/2006). The Fold. Leibniz and the Baroque, London \& New York: Continuum.

Deleuze, G. (2007). On Spinoza [Online]. Available: https://deleuzelectures. blogspot.com/2007/02/on-spinoza.html [Accessed 01 May 2020].

Deleuze, G. \& Guattari, F. (2002/1987). A Thousand Plateaus: Capitalism and Schizophrenia, London \& New York: Continuum.

Ellis, C. (2003). The Ethnographic I: A Methodological Novel About Autoethnography, California: AltaMira Press.

Handyside, S. \& Ringrose, J. (2017). Snapchat Memory and Youth Digital Sexual Cultures: Mediated Temporality, Duration, and Affect. Journal of Gender Studies 26 (3), pp. 347-360.

Haraway, D. (2016). Staying with the Trouble: Making Kin in the Chthulucene. Durham: Duke University Press.

Hastrup, K. (1990). The Ethnographic Present: A Reinvention. Cultural Anthropology 5(1), pp. 45-61.

Hollway, W. (2006). The Capacity to Care: Gender and Ethical Subjectivity, London: Routledge.

Jenkins, H., Ford, S. \& Green, J. (2013). Spreadable Media: Creating Value and Meaning in a Networked Culture, New York: NYU Press.

Johansen, K. B. H., Pedersen, B. M. \& Tjørnhøj-Thomsen, T. (2018). Visual Gossiping: Non-Consensual 'Nude' Sharing Among Young People in Denmark. Culture, Health \& Sexuality 21 (9), pp. 1029-1044.

Juelskjær, M. \& Rogowska-Stangret, M. (2017). A Pace of Our Own? Becoming Through Speeds and Slows: Investigating Living Through Temporal Ontologies of the University. Feminist Encounters: A Journal of Critical Studies in Culture and Politics 1 (1), pp.1-11. 
Juelskjær, M. \& Schwennesen, N. (2012). Intra-active Entanglements: An Interview with Karen Barad. Kvinder, køn og forskning 1-2, pp. 10-24. Kentridge, W. (2017). Thick Time. Louisiana Revy. Denmark: Louisiana Museum of Modern Art.

Kofoed, J. (2013a). Affektive Rytmer. Spektakularitet Og Ubestemmelighed I Digital Mobning. In: J. Kofoed \& D. M. Søndergaard, eds., Mobning gentæenkt. København: Hans Reitzels Forlag.

Kofoed, J. (2013b). Time to Think: Pace, Youth Life and Social Media. NCRM Methodological Innovation Network: Child in Time. Animating Ideas of Development and Transition. University of Sussex.

Kofoed, J. (2018). Temporal Ephemerality, Persistent Affectivity: Circulation of Intimacies on Snapchat. In: R. Andreassen, M. N. Petersen, K. Harrison \& T. Raun, eds., Mediated intimacies: Connectivities, Relationalities, and Proximities. London: Routledge.

Kofoed, J. \& Kousholt, D. (2011). Etiske fordringer og multiple temporaliteter. Nordiske Udkast. Tidsskrift for kritisk samfundsforskning 1/2, pp. 1-7.

Kofoed, J. \& Larsen, M. C. (2016). A Snap of Intimacy: Photo-sharing Practices Among Young People on Social Media. First Monday 21 (n.p.).

Kofoed, J. \& Ringrose, J. (2012). Travelling and Sticky Affects: Exploring Teens and Sexualized Cyberbullying Through a Butlerian-Deleuzian-Guattarian Lens. Discourse: Studies in the Cultural Politics of Education 33(1), pp. 5-20.

Kofoed, J. \& Staksrud, E. (2019). 'We Always Torment Different People, so by Definition, We Are No Bullies': The Problem Of Definitions In Cyberbullying Research. New Media \& Society 21(4), pp. 1006-1020.

Kofoed, J. \& Staunæs, D. (2015). Hesitancy as Ethics. Reconceptualizing Educational Research Methodology, 6(2), n.p.

Kofoed, J. \& Stenner, P. (2017). Suspended Liminality: Vacillating Affects in Cyberbullying/Research. Theory \& Psychology 27(2), pp. 167-182.

Lather, P. (2007). Getting Lost: Feminist Efforts toward a Double(d) Science, Albany: State University of New York Press.

Lather, P. \& St. Pierre, E. A. (2013). Post-Qualitative Research. International Journal of Qualitative Studies in Education 26(6), pp. 629-633.

Maclure, M. (2013). Classification or Wonder? Coding as an Analytic Practice in Qualitative Research. In: R. Coleman \& J. Ringrose, eds., Deleuze and Research Methodologies. Edinburg: Edinburgh University Press. 
Maclure, M. (2020). Inquiry as Divination. Qualitative Inquiry 27 (5), pp. 502-511.

MaddockS, S. (2018). From Non-Consensual Pornography to Image-based Sexual Abuse: Charting the Course of a Problem with Many Names. Australian Feminist Studies 33(97), pp. 345-361.

Massumi, B. (2015). Politics of Affect, Cambridge: Polity Press.

McGlynn, C. \& Rackley, E. (2017). Image-Based Sexual Abuse. Oxford Journal of Legal Studies 37(3), pp. 534-561.

Mortensen, S. U. (2020). Defying Shame. MedieKultur: Journal of Media and Communication Research 36(67), pp. 100-120.

Puig De La Bellacasa, M. (2017). Matters of Care: Speculative Ethics in More Than Human Worlds, Minneapolis: University of Minnesota Press.

Rasmussen, P. \& Søndergaard, D. M. (2020). Traveling Imagery. MedieKultur: Journal of Media and Communication Research 36 (67), pp. 076-099. Ringrose, J. \& Harvey, L. (2015). Boobs, Back-Off, Six Packs and Bits: Mediated Body Parts, Gendered Reward, and Sexual Shame In Teens' Sexting Images. Continuum 29(2), pp. 205-217.

Ringrose, J., Harvey, L., Gill, R. \& Livingstone, S. (2013). Teen Girls, Sexual Double Standards and 'Sexting': Gendered Value in Digital Image Exchange. Feminist theory 14(3), pp. 305-323.

Seigworth, G. J. (2019a). Element or Thresholds for Affect Study. Paper presented at AIE seminar, Copenhagen.

Seigworth, G. J. (2019b). Point, Line, And Plane. Affect, Interface, Event. Copenhagen: IT University.

Springgay, S. \& Truman, S. E. (2018). On the Need for Methods Beyond Proceduralism: Speculative Middles, (In)Tensions, and Response-Ability in Research. Qualitative Inquiry 24(3), pp. 203-214. Springgay, S., \& Truman, S. E. (2018). Walking Methodologies in a Morethan-Human World: WalkingLab. London \& New York: Routledge.

St. Pierre, E. A. (2017). Haecceity: Laying out a Plane for Post Qualitative Inquiry. Qualitative Inquiry 23(9), pp. 686-698.

St. Pierre, E. A. \& Jackson, A. Y. (2014). Qualitative Data Analysis After Coding. Qualitative Inquiry 20(6), pp. 715-719.

Staunæs, D. \& Kofoed, J. (2015). Producing Curious Affects: Visual Methodology as an Affecting and Conflictual Wunderkammer. International Journal of Qualitative Studies in Education, 28(10), pp. 1229-1248. 
Staunæs, D. \& Raffns $\emptyset$, S. (2019). Affective Pedagogies, Equine-assisted Experiments and Posthuman Leadership. Body \& Society 25(1), pp. 57-89.

Stewart, K. (2007). Ordinary Affects, Durham: Duke University Press.

Sylwander, K. R., \& Gottzén, L. (2020). Whore! Affect, Sexualized Aggression and Resistance in Young Social Media Users' Interaction. Sexualities, 23(5-6), pp. 971-986.

Sylwander, K. R. (2019). Affective Atmospheres of Sexualized Hate Among Youth Online: A Contribution to Bullying and Cyberbullying Research on Social Atmosphere. International Journal of Bullying Prevention 1, pp. 269-284.

Thomsen, B. M. S. (2018). Lars von Trier's Renewal of Film 1984-2014: Signal, Pixel, Diagram, Aarhus: Aarhus University Press.

Uldbjerg, S. (2020). Writing Victimhood: A Methodological Manifesto for Researching Digital Sexual Assault Kvinder, Køn \& Forskning 29, pp. 27-39.

Whatmore, S. (2003). Generating Materials. In: M. Pryke, G. Rose \& S. Whatmore, eds., Using Social Theory: Thinking through Research, London: Sage Publications. 